\title{
KAJIAN BANYAKNYA PUPUK KANDANG TERHADAP PERKEMBANGBIAKAN KUTU AIR (Daphnia sp.) DI RUMAH KACA SEBAGAI PAKAN ALAMI DALAM BUDIDAYA IKAN
}

\author{
Teddy Setyawan, Lilis Sugiarti, dan Supriyono Eko Wardoyo* \\ Prodi Biologi FMIPA UNB \\ Jl. KH Soleh Iskandar KM 4 Cimanggu Tanah Sareal, Bogor 16166 \\ *e-mail: supriyono.wardoyo@yahoo.com
}

\section{ABSTRACT
Study of manure amount for kutu air (Daphnia sp.) reproduction in green house as natural food in fish culture

\begin{abstract}
Daphnia sp. is zooplankton used as natural food fish that have a complete nutrient content and easily digested in the gastro intestinal tract because it is solid and has a thin wall, otherwise it does not cause a decline of water quality and can improve the durability of fish seed to disease or changes in water quality, because it is always in living conditions. Levels of nutrient content consists of $42.65 \%$ protein, $8 \%$ fat, fiber and ash 4\%. In the farming activities either fish growth or fish hatcheries $2.58 \%$ and ornament fish consumption, the daphnia is very desirable as a source of natural food and fresh for fish.The research result showed that the treatment with fertilizer concentration of $3 \mathrm{~g} / \mathrm{l}$ gave the highest average number of Daphnia sp. on the sixth day. The highest was 344,000 head in the water volume of 30 liters using aquariums in the greenhouse environment. Water quality during the study was an average water temperature of $33^{\circ} \mathrm{C}$ and an average $\mathrm{pH}$ of 6.45 and the water quality was an optimum condition for the growth of Daphnia sp. There was a negative correlation significantly between the average member of Daphnia sp. with a concentration of manure and $\mathrm{pH}$, but there was no correlation between the member of Daphnia sp. with the water temperature.
\end{abstract}

Keywords : Daphnia sp., manure amount, natural food, fish culture

\begin{abstract}
ABSTRAK
Daphnia sp. adalah zooplankton digunakan sebagai pakan alami ikan yang mempunyai kandungan gizi yang lengkap mudah dicerna dalam saluran pencernaan karena isinya padat dan mempunyai dinding yang tipis, selain itu tidak menyebabkan penurunan kualitas air dan dapat meningkatkan daya tahan benih ikan terhadap penyakit maupun perubahan kualitas air karena selalu dalam keadaan hidup dan kadar kandungan gizi terdiri dari protein 42,65\%, lemak $8 \%$, serat 2,58 \% dan abu $4 \%$ (Darmanto, dkk., 2000). Didalam kegiatan usaha budidaya atau pembenihan ikan baik ikan konsumsi maupun ikan hias, pakan alami ini sangat diperlukan sekali sebagai sumber makanan dari alam karena segar sesuai kesukaan ikan. Hasil penelitian bahwa perlakuan menghasilkan rata-rata jumlah Daphnia sp. pada fase stasioner hari keenam dengan konsentrasi pupuk $3 \mathrm{~g} / \mathrm{L}$ merupakan perkembangbiakkan Daphnia sp. tertinggi yaitu 344.000 ekor dalam volume air 30 liter menggunakan akuarium di dalam lingkungan rumah kaca. Kualitas air selama penelitian adalah rata-rata suhu air $33^{\circ} \mathrm{C}$ dan rata-rata $\mathrm{pH}$ 6,45 dan kualitas air ini merupakan kondisi optimum untuk pertumbuhan Daphnia sp. Ada korelasi negatif (berlawanan) secara nyata antara rata-rata perkembangbiakkan Daphnia sp. dengan konsentrasi pupuk kandang dan $\mathrm{pH}$, tetapi tidak ada korelasi antara perkembangbiakkan Daphnia sp. dengan suhu air.
\end{abstract}

Kata kunci: Daphnia sp., Konsentrasi Pupuk Kandang, pakan alami, budidaya ikan

\section{PENDAHULUAN}

Pakan alami ikan adalah sejenis pakan ikan berupa organisme baik tumbuh-tumbuhan maupun hewani yang hidup didalam perairan. Organisme tumbuh-tumbuhan ini secara ekosistem merupakan produsen primer atau tingkat makanan permulaan dalam rantai makanan. Ikan dalam memanfaatkan pakan alam ini tergantung daripada kebiasaan dan ukuran tubuh pakan itu sendiri. 
Didalam kegiatan usaha budidaya atau pembenihan ikan baik ikan konsumsi maupun ikan hias, pakan alami tersebut sangat diperlukan sekali sebagai sumber makanan dari alam karena segar sesuai kesukaan ikan. Pakan alami berupa hewan ini mempunyai kandungan gizi yang lengkap, mudah dicerna dalam saluran pencernaan ikan karena isinya padat dan mempunyai dinding yang tipis. Tidak menyebabkan penurunan kualitas air dan dapat meningkatkan daya tahan benih ikan dari penyakit maupun perubahan kualitas air karena hidup, cepat berkembangbiak dan pergerakannya tidak terlalu aktif sehingga mudah ditangkap.

Ukuran pakan alami ikan ini sangat kecil sehingga cocok dan sesuai dengan bukaan mulut larva dan benih ikan. Pada umumnya di perairan pakan alami berupa organisme kecil seperti fitoplankton, zooplankton, benthos, maupun organisme tingkat rendah lainnya seperti tubifek, siput, larva serangga air dan lain-lainnya.

Salah satu organisme pakan alami ikan adalah kutu air (Daphnia sp.) yang perlu untuk dibudidayakan sesuai kebutuhan, baik jenis maupun jumlah atau menangkapnya langsung dari perairan (Lampiran 1.). Agar ketersediaan pakan alami ikan dalam suatu usaha budidaya ikan tersedia secara berkesinambungan maka harus dilakukan budidaya pakan alami ikan. Untuk itu dibutuhkan pengetahuan tentang teknik budidaya pakan alami ikan agar kebutuhan pakan alami tersebut selalu tersedia.

Daphnia sp. merupakan udangudangan dan habitatnya di air tawar dan juga di air laut. Daphnia sp. merupakan makanan alami yang popular di kalangan pembudidaya ikan hias karena organisme ini memiliki kandungan gizi tinggi, segar dan dapat dibudidayakan (Mudjiman, 2004).

Perkembangan usaha budidaya ikan semakin hari semakin meningkat sejalan dengan kemajuan jaman dan teknologi. Pembudidaya ikan saat ini cenderung untuk memanfaatkan lahan yang tersedia semaksimal mungkin sehingga produksi per satuan luas juga semakin meningkat. Dengan semakin intensifnya usaha budidaya ikan tersebut, semakin terasa arti penting peranan makanan ikan yang salah satunya adalah Daphnia sp. untuk mempercepat laju pertumbuhan ikan. Sebagai pakan alami untuk tingkat burayak, benih, dan bahkan ikan hias dewasa, pembudidaya perlu mengusahakan dalam jumlah banyak dan kontinu. Pembudidaya harus mengetahui cara-cara budidaya pakan alami ikan salah satu diantaranya adalah Daphnia sp. Penyediaan Daphnia sp. melalui penangkapan di alam sangat tergantung pada musim, disamping beresiko membawa bibit penyakit dari luar budidaya (Djajadiredja, 1973).

Kadar kandungan gizi Daphnia sp. adalah protein $42,65 \%$, lemak $8 \%$, serat $2,58 \%$ dan abu $4 \%$ (Darmanto, dkk., 2000).

Dalam penelitian ini akan dilihat pengaruh jumlah pupuk kandang dari kotoran ayam terhadap budidaya Daphnia sp. didalam akuarium sebagai wadah pengembangbiakkannya di rumah kaca (Lampiran 2). Penggunaan pupuk kandang mengacu pada Priyambodo dan Wahyuningsih (2005) yaitu konsentrasi antara 2 - 5 gram/Liter dengan suhu air $26-27^{\circ} \mathrm{C}$, waktu panen mengacu pada Mudjiman (2008) yaitu antara 5 - 10 hari dan $\mathrm{pH}$ air mengacu pada Yeremia (2006) yaitu $\mathrm{pH}$ antara 6 9. Penelitian ini akan mengembangkan teknik budidaya Daphnia sp. di dalam lingkungan rumah kaca dengan kondisi lingkungan yang ada.

\section{BAHAN DAN METODA}

Penelitian yang dilakukan adalah bersifat percobaan (experimental) dengan 8 perlakuan yaitu konsentrasi pupuk kandang berurutan dari $0 \mathrm{~g} / \mathrm{L}, 1$ $\mathrm{g} / \mathrm{L}, 2 \mathrm{~g} / \mathrm{L}, 3 \mathrm{~g} / \mathrm{L}, 4 \mathrm{~g} / \mathrm{L}, 5 \mathrm{~g} / \mathrm{L}, 6 \mathrm{~g} / \mathrm{L}$ dan 7 g/L yang dimasukkan kedalam masing-masing akuarium dan 3 ulangan di dalam lingkungan rumah kaca untuk perkembangbiakkan Daphnia sp.. 
Rancangan percobaan yang digunakan adalah rancangan acak lengkap (RAL) (Hidayat dan Makarim, 1992), variabel yang diamati adalah jumlah Daphnia sp., suhu air dan $\mathrm{pH}$ setiap dua hari sekali dan hasilnya dianalisis dengan sidik ragam (Anova) dan uji lanjut Duncan menggunakan program statistik SPSS versi 13,0 (Statistical Product and Service Solution).

Masing-masing akuarium sebanyak 24 diisi dengan air sebanyak 30 liter, diberi kode yang berbeda pada setiap akuarium dan akuarium diletakkan dengan diacak sesuai RAL. Pupuk kandang ditimbang dan dimasukkan kedalam masing-masing akauarium yang berisi air sebanyak 30 liter (1:30), pupuk kandang dibungkus dengan bahan strimin, diberi pemberat secukupnya dan diikat dengan tali kemudian diletakkan ke dasar akuarium. Masing-masing akuarium diberi aerasi dengan alat aerator untuk membuang gas-gas beracun $\left(\mathrm{CO}_{2}, \mathrm{H}_{2} \mathrm{~S}\right.$ dan $\left.\mathrm{NH}_{3}\right)$ dari hasil penguraian kotoran ayam oleh bakteri, didiamkan selama 7 hari sehingga bau busuk di dalam air hilang, busa-busa air yang berada pada permukaan dibuang hingga terlihat pakan kutu air berwarna kecoklatan yaitu mikroalgae berupa fitoplankton dan bakteri.

Sejumlah Daphnia sp. berasal dari kolam budidaya air tawar di daerah Cibalagung, Bogor, diambil menggunakan plankton net sebanyak $350 \mathrm{ml}$ dan ditebarkan pada masing-masing akuarium sebanyak $15 \mathrm{ml}$ dengan jumlah rata-rata 225 ekor Daphnia sp..

Penghitungan Daphnia sp., pengukuran suhu air dan pengukuran $\mathrm{pH}$ pada masing-masing akuarium dilakukan setiap dua hari sekali untuk mengetahui kondisi masing-masing akuarium di dalam lingkungan rumah kaca. Dalam penghitungan jumlah Daphnia sp., sebelum pengambilan sampel, air diaduk dahulu hingga homogen agar Daphnia sp. yang berada dibawah naik dan merata. Sampel berupa air yang berisi Daphnia sp. diambil menggunakan gelas ukur sebanyak $15 \mathrm{ml}$, setiap akuarium diambil dari 5 titik yang berbeda dan masing-masing dituangkan ke dalam petridis. Kemudian dilakukan penghitungan, Daphnia sp. dapat dilihat langsung oleh mata telanjang, kaca pembesar atau mikroskop. Suhu air diukur menggunakan termometer yang secara langsung dimasukkan ke dalam air akuarium. Pengukuran $\mathrm{pH}$ dilakukan dengan mengambil air dari akuarium sebanyak $50 \mathrm{ml}$ dan diukur menggunakan $\mathrm{pH}$ meter.

\section{HASIL DAN PEMBAHASAN}

Hasil penelitian ini menunjukkan bahwa perlakuan menghasilkan rata-rata jumlah Daphnia sp. pada fase stasioner dimulai dari hari kelima sampai dengan hari kesepuluh sehingga pada hari keenam sudah dapat dilakukan pemanenan Daphnia sp. yaitu pertumbuhannya meningkat mulai pada konsentrasi pupuk $0 \mathrm{~g} / \mathrm{L}, 1 \mathrm{~g} / \mathrm{L}, 2 \mathrm{~g} / \mathrm{L}$ dan $3 \mathrm{~g} / \mathrm{L}$, tetapi menurun dengan bertambahnya konsen-trasi pupuk yaitu $4 \mathrm{~g} / \mathrm{L}$ dan mati pada konsentrasi pupuk kandang $5 \mathrm{~g} / \mathrm{L}$, $6 \mathrm{~g} / \mathrm{L}$ dan $7 \mathrm{~g} / \mathrm{L}$. Konsentrasi pupuk kandang $3 \mathrm{~g} / \mathrm{L}$ merupakan populasi/ perkembang-biakkan Daphnia sp. tertinggi yaitu 344.000 ekor. (Gambar 1.).

Pada pemberian pupuk dengan konsentrasi $1 \mathrm{~g} / \mathrm{L}$ menghasilkan pertumbuhan Daphnia sp. yang lebih kecil yaitu sebanyak 144.000 ekor dan $2 \mathrm{~g} / \mathrm{L}$ sebanyak 209.067 ekor, hal ini disebabkan kebutuhan pakan Daphnia sp. yaitu fitoplankton yang tersedia sedikit karena jumlah pupuk kandang yang mengalami pembusukkan juga sedikit. Pertumbuhan Daphnia sp. yang maksimal pada pemupukkan dengan konsentrasi $3 \mathrm{~g} / \mathrm{L}$ juga dapat dipengaruhi oleh kondisi lingkungan antara lain aerasi dan intensitas cahaya matahari yang cukup. Pupuk kandang memberikan pengaruh pada pertumbuhan Daphnia sp. karena mengandung unsur hara makro seperti Nitrogen (N), Fospat $\left(\mathrm{P}_{2} \mathrm{O}_{5}\right)$ dan Kalium $\left(\mathrm{K}_{2} \mathrm{O}\right)$ yang berpengaruh dalam proses fotosintesis pada fitoplankton. Pupuk kandang ini akan menjadi sumber nutrisi 
bagi kehidupan fitoplankton yang (Martosudarmo,1980). merupakan sumber pakan Daphnia sp.

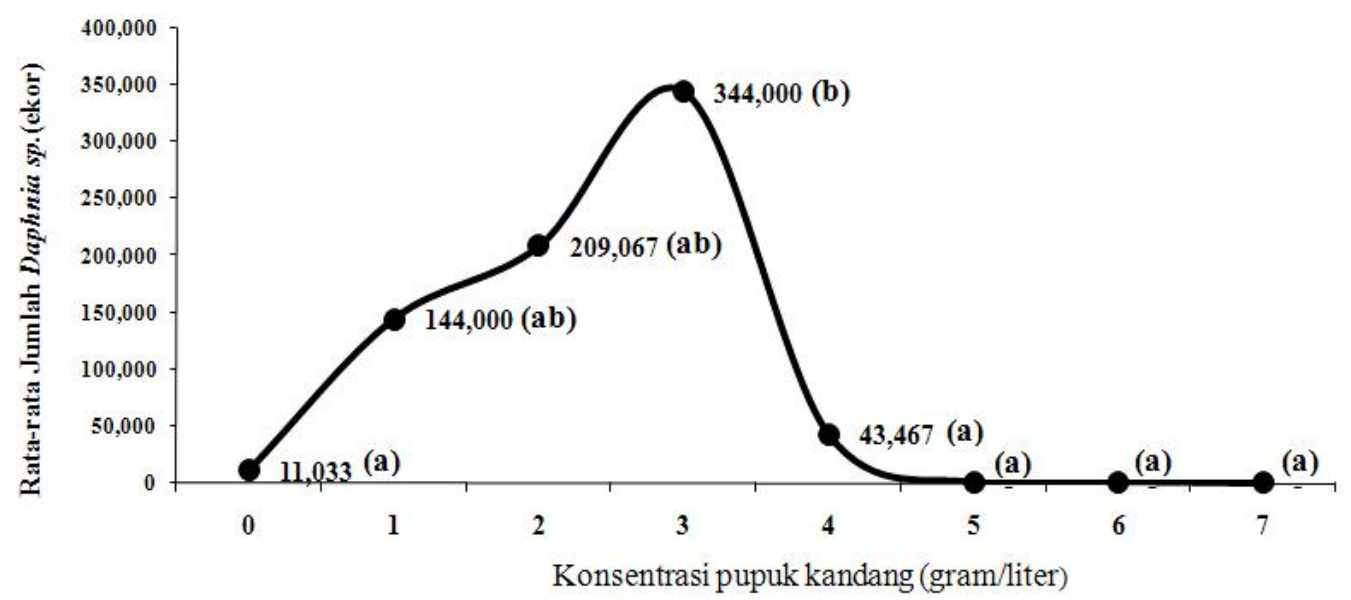

Ket.: - Angka-angka yang diikuti oleh huruf yang sama berarti perlakuan berpengaruh tidak nyata pada taraf $1 \%$;

- Jumlah Daphnia sp. dalam volume air 30 liter.

Gambar 1. Kurva Rata-rata jumlah Daphnia sp. pada hari keenam.

Kurangnya aerasi juga akan mengurangi kandungan oksigen yang terlarut di dalam air, pada konsentrasi pupuk $4 \mathrm{~g} / \mathrm{L}, 5 \mathrm{~g} / \mathrm{L}, 6 \mathrm{~g} / \mathrm{L}$ dan $7 \mathrm{~g} / \mathrm{L}$ meng-akibatkan proses pembusukkan terus berjalan. Proses pembusukkan ini akan menghasilkan gas-gas beracun seperti $\mathrm{CO}_{2}, \mathrm{H}_{2} \mathrm{~S}$ dan $\mathrm{NH}_{3}$ dalam jumlah lebih besar dan berkurangnya kualitas air yang dapat menghambat pertumbuhan Daphnia sp.. Selain menghasilkan gas beracun, fermentasi juga dapat me-naikkan suhu air serta $\mathrm{pH}$ sehingga diduga dapat menghambat pertumbuhan Daphnia sp. (Martosudarmo, 1980).

Untuk melihat apakah konsentrasi pupuk kandang berpengaruh nyata atau tidak terhadap perkembangbiakkan Daphnia sp. maka dilakukan analisis sidik ragam (Anova). Dasar pengam- bilan keputusan adalah jika nilai F-hit. lebih besar dari nilai F-tabel pada taraf 1 $\%$ berarti perlakuan berpengaruh sangat nyata terhadap perkembangbiakkan Daphnia sp. dan sebaliknya jika nilai Fhit. lebih kecil dari nilai F-tabel berarti perlakuan berpengaruh tidak nyata (Sutjitno,, 1992).

Konsentrasi pupuk kandang berpengaruh sangat nyata terhadap perkembangbiakkan Daphnia sp.. Berdasarkan analisis sidik ragam (Tabel 1.) bahwa nilai F-hit. $(6,349)$ lebih besar dari nilai F-tabel $(4,030)$ berarti perlakuan berpengaruh sangat nyata terhadap perkembangbiakkan Daphnia sp.. Karena perlakuan perbedaannya sangat nyata, maka untuk melihat konsentrasi pupuk yang berbeda sangat nyata diperlukan uji lanjut (uji Duncan).

Tabel 1. Hasil Analisis Sidik Ragam (Anova) Pengaruh Konsentrasi Pupuk Kandang terhadap Perkembangbiakkan Daphnia sp. pada Hari Keenam.

\begin{tabular}{lcrccc}
\hline \multicolumn{1}{c}{ SK } & JK & Db & KT & F-hit. & F-tabel 1\% \\
\hline Perlakuan & $342.556 .199 .583,33$ & 7 & $48.936 .599 .940,47$ & 6,349 & 4,030 \\
Galat & $123.317 .420 .000,00$ & 16 & $7.707 .338 .750,001$ & & \\
\hline Total & $465.873 .619 .583,33$ & 23 & & \\
\hline Ket.: SK (sumber keragaman), JK (jumlah kuadrat), Db (derajat bebas), KT (kuadrat tengah) dan F \\
(statistik F).
\end{tabular}


Hasil analisis uji Duncan (Sutjitno, 1992) pada taraf $1 \%$ (Tabel 2.) pada konsentrasi pupuk kandang 0 $\mathrm{g} / \mathrm{L}(\mathrm{A}), 1 \mathrm{~g} / \mathrm{L}(\mathrm{B}), 2$ (C) g/L, $4 \mathrm{~g} / \mathrm{L}(\mathrm{E})$, $5 \mathrm{~g} / \mathrm{L}(\mathrm{F}), 6 \mathrm{~g} / \mathrm{L}(\mathrm{G})$ dan $7 \mathrm{~g} / \mathrm{L}(\mathrm{H})$ berpengaruh tidak nyata. Hal ini dapat disebabkan pada konsentrasi pupuk kandang $0 \mathrm{~g} / \mathrm{L}, 1 \mathrm{~g} / \mathrm{L}$ dan $2 \mathrm{~g} / \mathrm{L}$ kurang mempengaruhi pertumbuhan fitoplankton sebagai pakan Daphnia sp., sedangkan pada konsentrasi pupuk kandang $4 \mathrm{~g} / \mathrm{L}, 5 \mathrm{~g} / \mathrm{L}, 6 \mathrm{~g} / \mathrm{L}$ dan $7 \mathrm{~g} / \mathrm{L}$ kemungkinan terdapat gas beracun dalam jumlah besar yang dapat menghambat perkembangbiakkan Daphnia sp., seperti pendapat Fauziah (2009) bahwa kotoran ayam dapat menim- bulkan gas berbau yang berasal dari unsur nitrogen dan sulfida, selama proses dekomposisi oleh mikroorganisme akan terbentuk gas amonia, nitrat, nitrit dan gas hidrogen sulfida. Konsentrasi pupuk kandang 3 g/L (D) berpengaruh sangat nyata dan merupakan konsentrasi yang relatif lebih baik untuk menghasilkan jumlah Daphnia sp. yang maksimal yaitu pada konsentrasi pupuk antara $2-5 \mathrm{~g} / \mathrm{L}$ Priyambodo dan Wahyuningsih (2005). Suhu air rata-rata di dalam akuarium tempat perkembangbiakkan Daphnia sp. yang diamati adalah $33{ }^{\circ} \mathrm{C}$ dan $\mathrm{pH}$ adalah 6,45 (Tabel 3.).

Tabel 2. Hasil Analisis Uji Duncan pada Hari Keenam.

\begin{tabular}{|c|c|c|c|c|c|}
\hline \multirow{2}{*}{$\begin{array}{l}\text { Konsentri } \\
\text { Pupuk } \\
\text { Kandang } \\
\text { (gram/Lite }\end{array}$} & \multirow[t]{2}{*}{ Kodee } & \multirow[t]{2}{*}{$\mathrm{N}$} & Hasil & \multicolumn{2}{|c|}{ Kelompok } \\
\hline & & & $\mathrm{a}$ & $\mathrm{b}$ & \\
\hline $\begin{array}{c}n \\
0\end{array}$ & (A) & 3 & $11.033,33$ & & $\mathrm{a}$ \\
\hline 1 & (B) & 3 & $144.000,00$ & $144.000,00$ & $a b$ \\
\hline 2 & (C) & 3 & $209.066,67$ & $209.066,67$ & $a b$ \\
\hline 3 & (D) & 3 & & $344.000,00$ & $\mathrm{~b}$ \\
\hline 4 & (E) & 3 & $43.466,67$ & & $\mathrm{a}$ \\
\hline 5 & $(\mathrm{~F})$ & 3 & 0,00 & & $\mathrm{a}$ \\
\hline 6 & (G) & 3 & 0,00 & & $\mathrm{a}$ \\
\hline 7 & (H) & 3 & 0,00 & & $\mathrm{a}$ \\
\hline Nyata & & & 0,019 & 0,17 & \\
\hline
\end{tabular}

Tabel 3. Rata-rata Suhu Air dan $\mathrm{pH}$ pada Hari Keenam.

\begin{tabular}{ccc}
\hline $\begin{array}{c}\text { Konsentrasi Pupuk } \\
\text { kandang } \\
\text { (gram/Liter) }\end{array}$ & Suhu $\left({ }^{\circ} \mathrm{C}\right)$ & $\mathrm{pH}$ \\
\hline 0 & 33 & 5,61 \\
1 & 33 & 6,20 \\
2 & 33 & 6,28 \\
3 & 33 & 6,53 \\
4 & 33 & 6,58 \\
5 & 33 & 6,69 \\
6 & 33 & 6,85 \\
7 & 33 & 6,89 \\
\hline Jumlah & 264 & 51,63 \\
\hline Rata-Rata & 33 & 6,45 \\
\hline
\end{tabular}


Pengamatan suhu air pada percobaan ini untuk melihat stabilitasnya selama pertumbuhan Daphnia sp. Pengamatan suhu air mulai dari hari ke nol hingga hari keenam pada masingmasing akuarium di rumah kaca tidak terlihat perbedaan cukup stabil yaitu pada kisaran 32,3 - 33,0 ${ }^{\circ} \mathrm{C}$. Kisaran suhu air pertumbuhan Daphnia sp. adalah $26-27{ }^{\circ} \mathrm{C}$, sehingga suhu air dalam penelitian ini lebih besar dan lebih stabil dibandingkan dengan suhu air yang dinyatakan oleh Priyambodo dan Wahyuningsih (2005). Tetapi pada percobaan ini terlihat pertumbuhan Daphnia sp. yang cukup baik. Suhu air dalam penelitian ini bisa digunakan untuk pertumbuhan fitoplankton sesuai kisaran suhu antara $16-36{ }^{\circ} \mathrm{C}$ dan $\mathrm{pH}$ antara 7 - 9 Cotteau (1996).

Hasil pengamatan $\mathrm{pH}$ terlihat sedikit penurunan (Lampiran 7.) dengan konsentrasi penambahan pupuk, yaitu pH pada kisaran 6 - 7. Meskipun demikian nilai $\mathrm{pH}$ tersebut masih pada kondisi $\mathrm{pH}$ yang optimum untuk pertumbuhan Daphnia sp. yaitu pH $6-9$ (Yeremia, 2006) dan untuk pertumbuhan fitoplankton yaitu $\mathrm{pH}$ antara 7 -9 (Cotteau, 1996).

Analisis korelasi (hubungan) antar variabel dalam penelitian ini bertujuan untuk mencari derajat keeratan hubungan dan arah hubungan. Semakin tinggi nilai korelasi, semakin tinggi keeratan hubungan kedua variabel. Hasil analisis korelasi terlihat bahwa ada korelasi negatif (berlawan) secara nyata antara perkembangbiakkan Daphnia sp. dengan konsentrasi pupuk kandang, artinya rata-rata semakin besar jumlah Daphnia sp. maka semakin kecil konsentrasi pupuk kandang yang dibutuhkan. Ada korelasi negatif secara nyata antara perkembangbiakkan Daphnia sp. dengan $\mathrm{pH}$, artinya semakin rata-rata besar jumlah Daphnia sp. maka semakin kecil pH yang dibutuhkan. Tidak ada korelasi antara perkembangbiakkan Daphnia sp. dengan suhu air (Tabel 4.).

Tabel 4. Hasil Data Analisis Korelasi antara Jumlah Daphnia sp. dengan pH dan Suhu air pada hari Keenam.

\begin{tabular}{|c|c|c|c|c|c|}
\hline \multicolumn{6}{|c|}{ Korelasi } \\
\hline & & $\begin{array}{c}\text { Jumlah } \\
\text { Daphniasp. }\end{array}$ & $\begin{array}{l}\text { Konsentrasi } \\
\text { Pupuk kandang }\end{array}$ & $\begin{array}{l}\text { Suhu air } \\
\left({ }^{\circ} \mathrm{C}\right)\end{array}$ & $\mathrm{pH}$ air \\
\hline \multirow[t]{2}{*}{ Daphina sp. } & $\begin{array}{l}\text { Koefesien korelasi } \\
\text { Nyata }\end{array}$ & 1,000 & $\begin{array}{r}-, 429^{*} \\
0,008\end{array}$ & & $\begin{array}{l}-, 342^{* *} \\
0,028\end{array}$ \\
\hline & Jumlah ulangan & 24 & 24 & 24 & 24 \\
\hline \multirow[t]{2}{*}{$\begin{array}{l}\text { Konsentrasi Pupuk- } \\
\text { kandang (gram) }\end{array}$} & Koefesien korelasi & $-.429^{*}$ & 1,000 & . & $0,438^{*}$ \\
\hline & $\begin{array}{l}\text { Nyata } \\
\text { Jumlah ulangan }\end{array}$ & $\begin{array}{r}0,008 \\
24\end{array}$ & 24 & 24 & $\begin{array}{c}0,004 \\
24\end{array}$ \\
\hline \multirow[t]{3}{*}{ Suhu Air $\left({ }^{\circ} \mathrm{C}\right)$} & Koefesien korelasi & . & . & . & . \\
\hline & Nyata & . & & & \\
\hline & Jumlah ulangan & 24 & 24 & 24 & 24 \\
\hline \multirow[t]{3}{*}{ pHAir } & Koefesien korelasi & $-342^{* *}$ & 0,438 * & . & 1,000 \\
\hline & Nyata & 0,028 & 0,004 & & . \\
\hline & Jumlahulangan & 24 & 24 & 24 & 24 \\
\hline
\end{tabular}

Ket.: - Tanda positif menunjukkan arah hubungan searah. Jika variabel naik berarti variabel yang lain naik;

- Tanda negatif menunjukkan hubungan berlawanan. Jika satu variabel naik berarti variabel yang lain akan menjadi turun;

- * taraf $1 \%$ dan ** taraf $5 \%$. 


\section{KESIMPULAN}

Rata-rata jumlah Daphnia sp. pada fase stasioner hari keenam dengan konsentrasi pupuk $3 \mathrm{~g} / \mathrm{L}$ merupakan perkembang biakkan Daphnia sp. tertinggi yaitu 344.000 ekor dalam volume air 30 liter menggunakan akuarium di dalam lingkungan rumah kaca. Kualitas air selama penelitian adalah rata-rata suhu air $33{ }^{\circ} \mathrm{C}$ dan rata-rata $\mathrm{pH} 6,45$ dan kualitas air ini merupakan kondisi optimum untuk pertumbuhan Daphnia sp.. Ada korelasi negatif /berlawanan secara nyata antara ratarata perkembang biakkan Daphnia sp. dengan konsentrasi pupuk kandang dan $\mathrm{pH}$, tetapi tidak ada korelasi antara perkembang biakkan Daphnia sp. dengan suhu air.

\section{DAFTAR PUSTAKA}

Cotteau. 1996. Budidaya Pakan Alami Ikan Plankton dan Benthos: Pusat Pengembangan dan Pemberdayaan Pendidikan dan Tenaga Kependidikan (PPPTK) Pertanian. Jember.

Darmanto, Satyani. D, Putra. A, Chumadi dan Rochat. D. M. 2000. Budidaya Pakan Alami untuk Benih Ikan Air Tawar: IPPTP. Jakarta. (Unpublished).

Djajadiredja, R. dan Z., Djangkaru, 1973, Metode Baru Pemeliharaan Ikan dengan Pemberian Makanan, Pemberitaan LPPD No. 1. Jakarta.

Fauziah. 2009. Upaya Pengelolaan Lingkungan Usaha Peternakan Ayam: Jurnal Lingkungan, Vol. 7, No. 13.

Gusrina. 2002, Budidaya Zooplankton: Departemen Pendidikan Nasional. Jakarta.
Hariyati. R. 2008. Pertumbuhan dan Biomassa Spirulina sp. dalam Skala Laboratoris: Jurnal Bioma, ISSN: 1410-8801, Vol. 10, No. 1.

Hidayat. A dan Makarim. A. K.1992. Pengambilan dan Persiapan Contoh Tanah dan Tanaman: Balai Penelitian dan Pengembangan Pertanian. Bogor.

Martosudarmo, B. 1980. Culture of Food Orgnism, di dalam Report of the Training Course on Prawn Farming for Asia and the Pasific, Jepara.

Mudjiman, A. 1983. Laporan Hasil Latihan Budidaya Artemia di Ghent, Belgia, 2-21 Mei 1988 Surabaya: Dinas Perikanan Daerah Propinsi Jatim.

Mudjiman, A. 2008. Makanan Ikan. Seri Agriwanesan. Situbondo. hal. 96.

Priyambodo. K dan Wahyuningsih. T. 2003. Budidaya Pakan Alami Ikan: Penebar Swadaya. Jakarta.

Setyawan. T. 2009. Budidaya Kutu Air (Daphnia sp.) di dalam Rumah Kaca dan di luar Rumah Kaca tidak Terkena Cahaya Matahari Langsung: PKL-UNB. (Unpublished).

Sutjihno. 1992. Pengantar Rancangan Percobaan Penelitian Pertanian: Balai Penelitian Tanaman Pangan. Bogor.

Versichele, D. Dan P. Sorgeloos. 1980. Controlled Production of Artemia Cysts in Batchcultures. The Brine Shrimp Artemia Vol. 3, Ecology, Culturing, Use in Aquaculture. (Wattern: Universal Press).

Yeremia. 2006. Cara Praktis Budidaya Kutu Air (Daphnia sp.) sebagai Pakan Ikan Hias: Penebar Swadaya. Jakarta. 
Lampiran 1. Daphnia sp

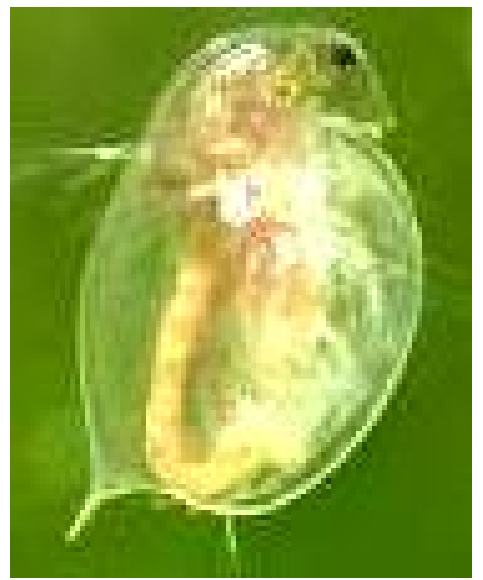

Gambar 1. Daphnia sp. (Yeremia, 2006).

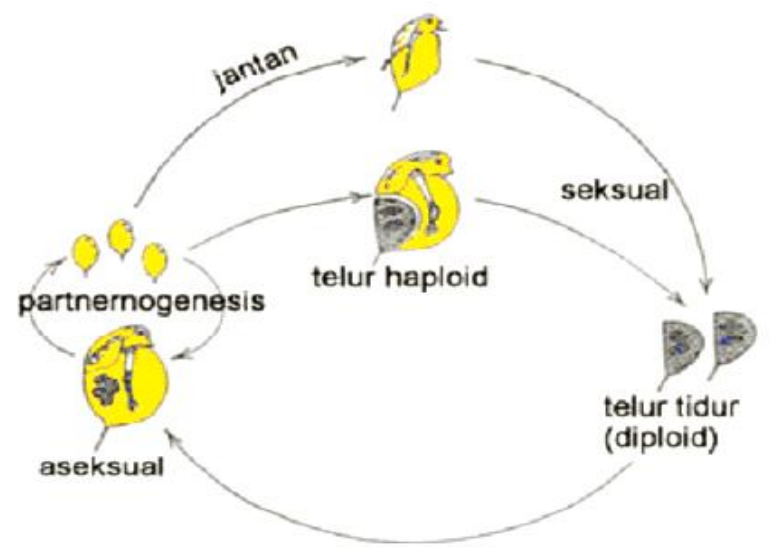

Gambar 2. Siklus Hidup Daphnia sp. (Yeremia, 2006)

\section{Daphnia.}

Klasifikasikan Daphnia sp. (Gusrina, 2002) Philum: Arthropoda, Kelas: Crustacea, Sub Klas: Branchiopoda,Ordo: Phylopoda, Sub Ordo: Cladocera, Genus: Daphnia, Spesies: Daphnia sp.

Daphnia sp. hidup pada perairan tawar dan sebagian besar hidup planktonik yang hanya mengikuti arus air. Hidup sebagai penghuni di sela-sela tumbuhan air di danau, waduk, rawa dan kolam. Ada juga yang hidup sebagai penghuni dasar (Mudjiman, 1983).

Daphnia sp. merupakan udang-udangan yang telah beradaptasi pada kehidupan badan perairan yang secara periodik mengalami kekeringan. Oleh karena itu, dalam perkembangbiakkannya dengan melahirkan namun dapat dihasilkan telur berupa kista. Telur berupa kista ini dapat bertahan terhadap kekeringan dan dapat tertiup angin kemana-mana, sehingga tidak mengherankan kalau tiba-tiba dalam genangan air disekitar rumah kita ditemukan Daphnia sp. (Vershicele dan Sorgeloos, 1980). 
Lampiran 2. Hydra (musuh), Plankton (makanan), dan Sinar Matahari (energy) bagi Daphnia
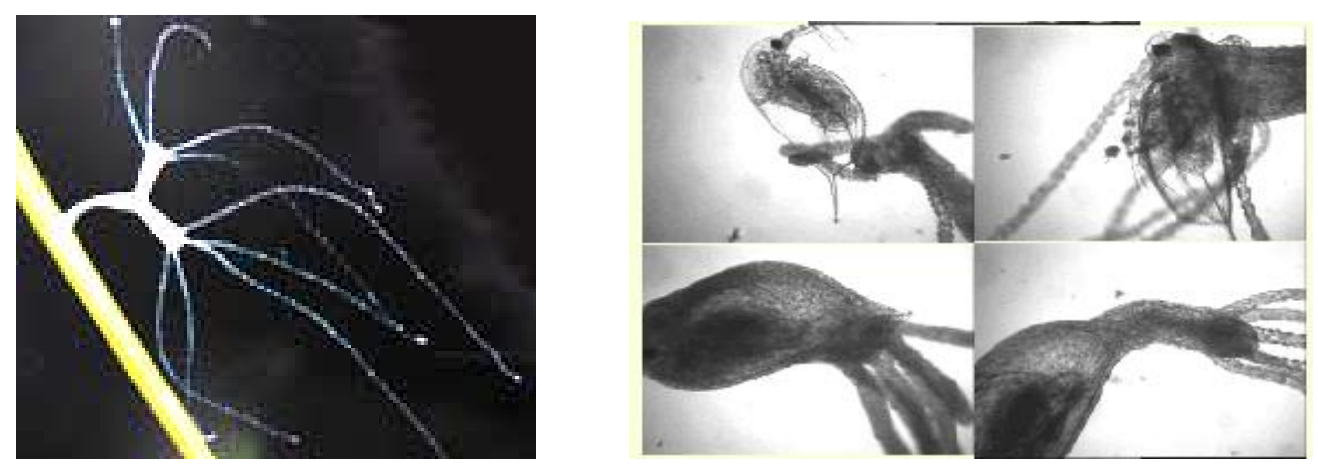

Gambar 3. Hydra sp. Menempel dan Memangsa Daphnia (Yeremia, 2006).

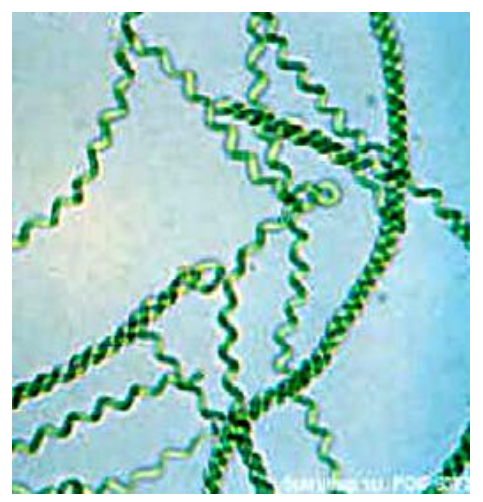

Gamabr 4. Plankton Spirulina sp. (Hariyati, 2008).

\section{Hydra (musuh), plankton (makanan), dan sinar matahari (energy) bagi daphnia}

Kotoran yang dihasilkan ternak itu ada dua macam yaitu pupuk kandang segar dan pupuk kandang yang telah membusuk. Pupuk kandang segar merupakan kotoran yang dikeluarkan hewan ternak sebagai sisa proses makanan yang disertai urine dan sisa-sisa makanan lainnya. Sedangkan pupuk kandang yang telah membusuk adalah pupuk kandang yang telah disimpan lama sehingga telah mengalami proses pembusukan atau penguraian oleh jasad renik (mikroorganisme).

Pupuk kandang mengandung unsur hara makro seperti Nitrogen (N), Fospat (P2O5) dan Kalium (K2O). Meskipun jumlahnya tidak banyak, dalam limbah ini juga terkandung unsur hara mikro diantaranya Kalsium (Ca), Magnesium (Mg), Tembaga (Cu), Mangan (Mn) dan Boron (Bo) (Fauziah, 2009).

Zat hara dibutuhkan untuk mencukupi pertumbuhan. Proses mengaktifkan kembali mikroorganisme yang ada di dalam pupuk kandang dapat melalui proses biologis maupun 
kimia, mendorong atau memacu aktivitas kehidupan jasad renik misalnya plankton (Fauziah, 2009).

Rumah kaca adalah sebuah rumah yang atap dan dinding sekelilingnya terbuat dari kaca/plastik. Rumah kaca menjadi panas karena radiasi elektromagnetik yang datang dari matahari memanaskan tumbuhan, tanah, barang/benda dan semua isi lainnya di dalam bangunan ini. Kaca yang digunakan untuk rumah kaca bekerja sebagai medium transmisi yang dapat memilih frekuensi yang berbeda-beda dan efeknya adalah untuk menangkap energi di dalam rumah kaca yang memanaskan di dalamnya, mencegah udara naik ke atas dan mengalir keluar. 